\title{
History and adaptation stories of the vertebrate fauna of southern Spain's semi-arid habitats 9
}

\author{
F. Valera ${ }^{\text {a, }}$, C. Díaz-Paniagua ${ }^{\text {, }}$, J.A. Garrido-García ${ }^{\text {b }}$, J. Manrique ${ }^{\text {, }}$, J.M. Pleguezuelos ${ }^{\text {d }}$, F. Suárez ${ }^{\text {e }}$ \\ ${ }^{a}$ Dept. de Ecología Funcional y Evolutiva, Estación Experimental de Zonas Áridas (CSIC), Carretera de Sacramento s/n, La Cañada de San Urbano, E 04120 Almería, Spain \\ ${ }^{\mathrm{b}}$ Estación Biológica de Doñana (CSIC), Avda. Américo Vespucio s/n, E 41092 Sevilla, Spain \\ ${ }^{c}$ IES Celia Viñas, Javier Sanz, 13 E-04004 Almería, Spain \\ ${ }^{\mathrm{d}}$ Dept. Biología Animal, Fac. Ciencias, Univ. Granada, E-18071 Granada, Spain \\ ${ }^{\text {e }}$ Dept. Ecología, Universidad Autónoma, Darwin 2, E-28049 Madrid, Spain
}

\author{
Keywords: \\ Adaptability \\ Aridity \\ Conservation \\ Natural history \\ Palaeoenvironment \\ Southeastern Spain \\ Vertebrate community
}

\begin{abstract}
a b s t r a c t
Southern Spain's semi-arid habitats are a Mediterranean ecosystem modelled mainly by historic factors which make them unique in comparison with North African deserts. Southern Spanish vertebrates have adapted to the recent emergence of semi-arid habitats in varying degrees of success. This paper reviews the current status of these terrestrial vertebrates (amphibians, reptiles, birds and mammals), their origins and their main features in relation to this biogeographic area. The vertebrate fauna of the semi-arid southeast of the Iberian peninsula differs widely from the one in the semi-arid Maghreb mainly because the former is composed by generalist vertebrates and much less so by species adapted to arid conditions. Moreover, a large fraction of the vertebrates in the semi-arid Iberia does not exploit the semiarid areas but depends on riparian and human-managed habitats. The species diversity is rather low since only a small fraction of Palaearctic, European or Mediterranean species can adapt to the ecological limitations imposed by aridity and dwell in these semi-arid habitats. Such adaptations comprehend features like trophic plasticity, low morphological specialization, high dispersal ability, shortened life cycles and behavioural mechanisms to exploit the limited resources available. This paper identifies major conservation issues and proposes specific courses of action.
\end{abstract}

1. Introduction: the history of a semi-desert without desert vertebrates

The biota of the southeastern Iberian semi-arid habitats and the biota of North African deserts and of the Middle East find their origins in the Mediterranean Sea desiccation during the Messinian (5.6 My BP) (Agustí and Antón, 2002; Vera, 2004). However, the Iberian southeast evolved differently from other western Palaearctic semi-deserts and true deserts. Firstly, when the Mediterranean filled up again, the Iberian peninsula became isolated from northern Africa as well as from the influence of the Middle East via northern Africa. Also, the impact of cold and wet Pleistocenic cycles on the Iberian southeast was much stronger than on the Maghreb or the Middle East. As a result of both factors, the semi-arid

\footnotetext{
q This paper is dedicated to the memory of the late Francisco Suárez. * Corresponding author. Tel.: p34 950 281045; fax: p34 950277100. E-mail address: pvalera@eeza.csic.es (F. Valera).
}

environments of today's Iberian southeast appeared thousands of years after the Messinian Crisis.

In the Atlantic period (7000e5500 years BP), the desert flora was confined to the poorest or most saline soils of the Iberian southeast. By contrast, the forests and thick Mediterranean shrubland (Pinus halepensis, Olea europaea, Pistacia lentiscus, Quercus coccifera) prevailed except in places with humid soils where riparian forests with species of dry and subhumid ombroclimate grew (Quercus rotundifolia, Quercus pyrenaica, Quercus faginea, Acer granatensis) (Costa et al., 1998; Valle, 2003). The latter habitats proved crucial for the increase in biodiversity at a regional scale, as they became lineal corridors supporting Mediterranean and Euro-Siberian aquatic and forest flora and fauna (Arrébola et al., 2000; Garrido-García, 2008; Navarro et al., 1998; Pleguezuelos, 1992). The semi-arid areas developed from the heavy deforestation of the area in the Bronze Age (1800e1500 B.C.), which caused desert vegetation to spread (Burjach et al., 1996; Navarro et al., 1998; Pantaleón-Cano et al., 2003). Therefore, this region must have had a typically Mediterranean Iberian vegetation in the middle phase of the Holocene, very much like what can still be found in the rest of southern Spain 

(Costa et al., 1998; Valle, 2003). By contrast, the vegetation that prevails today in southeastern semi-arid zones consists mainly in therophytic grasslands, chamephyte Labiatae and Fabaceae (Genista sp., Rosmarinus officinalis, Thymus sp.), open halonitrophilous shrubland (Salsola sp., Suaeda sp., Atriplex sp., Artemisa barrerieli) and dense Macrochloa tenacissima (Stipa tenacissima or esparto, hereafter) and Lygeum spartium. Virtually lacking in any tree vegetation, they are, somewhat justifiably, viewed locally as 'deserts', even if they do not belong in the category of Saharo-Sindhic deserts, not only in terms of their rainfall (usually above $200 \mathrm{~mm} /$ year) but also of their flora (Charco, 1999). Actually, these areas display features of other originally Mediterranean forest habitats, where human activity resulted in steppification and therophytization (Quézel and Médail, 2003). These areas should thus be classified as anthropic pseudo-steppes or semi-deserts.

In the southeast of the Iberian peninsula the semi-arid areas reached their definitive configuration in the Middle Ages, when riparian forests were destroyed by the increase in irrigated cultivations (Bertrand and Sánchez-Viciana, 2006). This desertification process and other anthropic influences had a major impact on vertebrates, as can be seen from the intense mammal fauna renewal of that time (Garrido-García, 2008). These semi-deserts are therefore young and have clear anthropic origins, which brings them closer to the formation of Mediterranean habitats than to the formation of desert habitats (Blondel and Aronson, 1999).

The above processes have resulted in a totally different biota from that of other Mediterranean deserts and semi-deserts. While endemic desert plants and insects of Saharo-Sindhic and Iranian-Turanic corology are common in southeastern Iberia today, the vertebrates feature mainly generalist species typical of open or shrubby habitats. The eremic flora and entomofauna survived by adapting both to arid and high mountain habitats, or by inhabiting edaphoxeric or halophilous coastal microrefugia. By contrast, desert termophilous vertebrates could not adapt to such habitats, because the habitats were neither large enough nor ecologically diverse enough to support them (Barbadilloet al., 1997; Martí and del Moral, 2003; Sánchez-Piñero, 2007; Suárez, 1992). Actually, the reappearance of the Mediterranean and the quaternary climatic cycles caused families of vertebrates whose evolution is well-known and which today are common in North African semi-deserts to disappear (Agamidae, Chamaeleonidae, Varanidae and Erycidae among reptiles, and Gerbilidae among mammals) (Agustí and Antón, 2002; Bailón, 1991; Barbadillo et al., 1997).

It will be shown below that semi-arid vertebrate communities seem poorer in southeastern Iberia compared with the specialized Saharan biotas. Still, it is worth finding out how the vertebrates of the Iberian southeast adapted to aridity and which type of community changes have arisen from the new selective forces which gave rise to these assemblages.

\section{Fauna composition}

\subsection{Amphibians}

No desert amphibian species occur in the semi-arid zones of southeastern Spain. Instead, we find the same species there which can be found in surrounding areas, except with a gradual richness impoverishment. This may be explained by the semi-arid characteristics of southeastern Spain, where aquatic habitats are scarce, and also by the dependence of most amphibians on the availability of breeding sites to sustain their populations. In this geographic basin, the number of amphibians tends to decrease from west to east. It shows significant correlations with rainfall-related variables such that more species coexist in sites with maximum values of absolute rainfall (Real et al., 1993).

Based on the data of amphibian distribution (González-Miras et al., 2003; Pleguezuelos et al., 2002; Tejedo et al., 2003; Torralva et al., 2005), and taking into consideration only areas with mean annual rainfall below $350 \mathrm{~mm}$ (semi-arid zones of Almería and Murcia provinces), the maximum number of species recorded was eight. However, using a grid of $10 \times 10 \mathrm{~km} \mathrm{UTM}$ squares, $17 \%$ of squares did not host any amphibians, and $27 \%$ included only one amphibian species (most often, either the Iberian water frog, Pelophylax perezi, or the Natterjack toad, Bufo calamita). Only one square $(0.5 \%)$ included the maximum number of five coincident species. Similar species richness is found in semi-arid regions of northern Africa (Bons and Geniez, 1996; Schleich et al., 1996). These include two of the southeastern Iberian species as well as sibling vicarious species that differ from other species of our study area only slightly (e.g. Alytes maurus, Pelophylax saharicus, Discoglossus pictus scovazzi) (Bons and Geniez, 1996).

The most frequent species in our study area, P. perezi, requires stable aquatic habitats. Its high abundance in this semi-arid area may be explained in terms of human influence, as this species dwells mainly in man-made watering constructions used for agriculture. The Common toad (Bufo bufo) also reaches high frequencies and uses this kind of habitats, as it commonly breeds in permanent water bodies. The second dominant species is B. calamita. It can be considered as the dominant species in natural aquatic habitats, mainly temporary ponds with short hydroperiods. Other amphibian species reach low frequencies, including species that breed typically in temporary ponds, such as the Spanish painted frog (Discoglossus jeanneae), the Parsley frog (Pelodytes punctatus) and the Mediterranean tree frog (Hyla meridionalis), and two species of midwife toads (genus Alytes) in the limits of their range. The latter two species are probably associated with artificial constructions. By contrast, in this semi-arid extreme of the Iberian peninsula, the absence of urodeles and Western spadefoot toad (Pelobates cultripes), a widespread anuran that needs long lasting temporary ponds for breeding, is a characteristic feature.

\subsection{Reptiles}

The semi-arid southeast of the Iberian peninsula hosts sixteen native and four non-native reptiles, most of the latter due to early introductions. This fauna is poorer than the one in the region at the end of the Miocene or during the Pliocene, and it does not include any real desert species. Reptiles adapted to arid environments have lived in the Iberian peninsula since the Messinian and probably earlier. They belong to the Agamidae, Chamaeleonidae, Varanidae, Erycidae and Elapidae families. Some of these families remained in the Iberian peninsula until as late as the lower Pleistocene but, apparently, did not survive glaciations (Bailón, 1991; Barbadillo et al., 1997). These families can currently be found in the close semi-arid and desert regions of northwestern Africa.

Among the native species, six are endemic to the Iberian peninsula and ten are widespread in the western Mediterranean Basin. Most of the Iberian endemic species (five out of six, namely the Iberian amphisbenian Blanus cinereus, the Spanish tree-toed skink Chalcides bedriagai, the Iberian wall lizard Podarcis hispanica, the Ocellated lizard Timon lepidus and the Spanish psammodrome Psammodromus hispanicus) have sibling species in northern Africa (Blanus tingitanus, Chalcides parallelus, Podarcis vaucheri, Timon tangitanus and Psammodromus microdactylus, respectively). This suggests the importance of vicariant speciation between populations separated by the Strait of Gibraltar, 5.3 My ago. However, the high percentage of other species in common with northwestern Africa (62.5\%) also suggests overseas migration after 
the formation of the strait. None of the four European reptiles relict everywhere else in the southern half of the Iberian peninsula (Emys orbicularis, Lacerta schreiberi, Coronella austriaca and Natrix natrix) have populations in the semi-arid southeast.

\subsection{Birds}

The species composition and richness of the bird community of semi-arid zones in the southeast of the Iberian peninsula are difficult to establish due to the marked bioclimatic and topographic changes caused by the neighbouring mountains (Capel, 1990). These changes have dramatic effects on bird communities in short distances.

According to the basal bioclimatic level (namely thermomediterranean, generally the most arid one in southeastern Spain), the breeding bird communities comprehend 47 species (Appendix A), excluding those which are characteristic of wetlands, coasts and humanized habitats. The species richness found here does not allow true comparison with the richness of other areas. The breeding bird atlas of Almería province (Manrique, 1996) and the richness distribution according to altitude show that, by comparison, the poorest grids are those of the semi-arid thermomediterranean, whereas the richest grids appear in higher bioclimatic levels. The former are low-relief and a good part of their surface is cultivated. The latter are mature, fragmented forests, with shrubland and traditional farmland. Similar results were found by Pleguezuelos (1992) in other parts of eastern Andalusia. These studies show that a greater extension of ramblas may result in significant increases in bird community richness in the region.

The contrast between the bird fauna composition of southeastern Iberian and North African arid and semi-arid regions also depends on the range of habitats and the spatial scale under consideration in both areas. According to the data of flat areas or with undulated relief in southeastern Spain (Tellería et al., 1988), of northern African semi-arid areas (Blondel, 1962; Suárez et al., 1986), and of the Sahara desert (Suárez, unpubl. results), Saharan communities differ widely from those of the Iberian southeast (Appendix B). The estimated concordance between Saharan communities and the Iberian southeast is $23 \%$ as measured with Cole's index (S 1/4 $100 \times 2 \times$ number of shared species/(spp a $p$ spp b)). Typically Saharan species are virtually missing in Spain (e.g. the two species of genus Ammomanes, Alaemon alaudipes, Ramphocoris clotbey, Sylvia nana, Scotocerca inquieta, etc.; Appendix B). The only breeding species in both communities are the Trumpeter finch Bucanetes githagineus, the Black Wheatear Oenanthe leucura, the Crested Lark Galerida cristata and the Little owl Athene noctua. Remarkably, nearly no Saharan species are reported as occasional visitors in the peninsula (De Juana, 2006). Greater concordance is found between the composition of the southeastern ramblas and Saharan oasis, as a number of species are in common (e.g. Turdus merula, Luscinia megarhynchos).

By contrast, the composition of pre-Saharan communities in Maghreb is rather similar to that of the Iberian southeast (Cole's index $1 / 472 \%)$. In fact the concordance is greater than that between North African arid and semi-arid areas (Cole's index $1 / 4 \quad 36 \%$, Appendix B). The lark species are basically the same, although Eremophila bilopha is found in northern Africa but not in the Iberian southeast. Oenanthe species are more diverse in northern Africa too: Oenanthe deserti and Oenanthe moesta are widespread there, but they are not recorded in Spain. Saxicola torquata is the only species which is relatively frequent in Spain (provided medium height shrub) and which is not frequent in pre-Saharan habitats. Dupont's lark Chersophilus duponti is an outstanding case. Laiolo and Tella (2006a) and Vögeli et al. (2010) showed that vegetation structure rather than floristic distribution influences the distribution of this bird species at different spatial scales. However, García et al. (2008a) suggest some influence of floristic composition. In Morocco the latter research found the highest density of this lark in well-preserved esparto fields of S. tenacissima, while in the Iberian peninsula the same species uses shrublands except for two areas of the southeast, where it uses esparto fields too (Suárez, 2010). Remarkably, esparto fields are widespread elsewhere in the southern half of the Iberian peninsula. Suárez (2010) has recently suggested that the different distribution pattern in both regions could be due to morphological differences between the populations of the two continents and to the different degree of vegetation cover. The sharp decrease of Ch. duponti in the Iberian southeast is discussed in Section 3.3.

Saharan species are most probably missing from pre-Saharan areas because they are not adapted to semi-arid habitats or due to competition with the more abundant Mediterranean species adapted to pre-Saharan areas. By contrast, it is more difficult to explain why certain pre-Saharan species are not found in the Iberian peninsula. It can be hypothesized that Maghreb preSaharan habitats are much larger than the semi-arid southeastern Iberian ones and somewhat more diversified as regard vegetation structure. This may explain higher species richness and ensuing differences in community composition. It can also be hypothesized that the exchange between the pre-Saharan and the Iberian southeastern fauna is weak: the Mediterranean is a constraint on genetic flux between areas. Three arguments support the latter hypothesis: i) the subspecies of many species are different in Morocco and in Spain, for example G. cristata (Guillaumet et al., 2004, 2006); ii) the only steppe species researched for genetic links between the two areas, Ch. duponti, has been proved to currently have virtually no genetic flux (García et al., 2008b); and iii) few species of pre-Saharan areas have been recorded in Spain, namely Cursorior cursor and O. deserti (De Juana, 2006).

In a comparison within the limits of the Iberian peninsula, the breeding communities of the semi-arid southeast are very similar to the ones in the Ebro Valley (northeast), even if the latter host a species which is not found in the southeast, namely Pterocles alchata (Hernández and Pelayo, 1987). In turn, one of the characteristic species of the southeast, B. githagineus, has been recorded in the Ebro Valley in the breeding season (Molina et al., 2010).

The bird communities in southeastern semi-arid Spain are dominated by the Mediterranean and Turkestan-Mediterranean types, with occasional desert introgressions (B. githagineus) and EuroSiberian and Holarctic introgressions, the latter mainly in the ramblas. Thus, virtually half of the 47 species mentioned at the beginning of this section (i.e. 47\%) show any of the former two faunal types of distribution. The European and Turkestan-European species are comparatively less frequent (19\%, Appendix A). Except for the Palaearctic and Paleoxeric types, the occurrence of species of the remaining types is close to or under $5 \%$. These percentages vary widely among the three more important landscapes: i) natural vegetation plains with occasional dry cereal farming; ii) ramblas with riparian vegetation and tree orchards; and iii) sparse olive and almond trees. Bird species in greenhouse cultures are discussed further below.

The first habitat type is dominated by Mediterranean and Turkestan-Mediterranean faunal types (55\%), the remaining types being comparatively minor (Ç14\%). In the ramblas, the dominating type is also Mediterranean and Turkestan-Mediterranean (42\%). The Euro-Turkestan and Palaearctic species reach together 29\%. In the latter habitat type, the Mediterranean and TurkestanMediterranean and the European and Euro-Turkestan prevail (43 and $30 \%$, respectively). The ramblas therefore foster the northernmost species, in contrast to the positive effect of plain areas for the Mediterranean species. In the thermomediterranean bioclimatic level, the species richness of ramblas is higher than in plains with 
occasional cultivations and in olive and almond orchards (31, 22 and 23 breeding species, respectively).

The winter community composition is, at least in the plains, similar to the composition during the breeding season. Still, the winter community hosts a number of Euro-Siberian species (e.g. Alauda arvensis and Anthus pratensis) probably from central and northern Europe, as well as other species with altitudinal movements (e.g. Phoenicurus ochruros) and fringillids (e.g. Carduelis chloris, Carduelis cannabina and Serinus serinus) of unknown origin. This is different in the pre-Saharan areas (except for C. cannabina, which is a common wintering species), where the European species are scarce, whereas northwards movements of Saharan species seem to occur and, at least in some years, increase remarkably in density in winter (e.g. B. githagineus, R. clotbey or E. bilopha).

A major feature of the landscape in the semi-arid Iberian southeast is the large greenhouse cultivations which started on the coast and spread inland recently. These cultivations lie both in plains and in ramblas, and they have strong negative effects on bird communities: of the species listed in Appendix A, only Galerida theklae and Sylvia conspicillata manage to survive in the few shrubs remaining next to the greenhouses.

\subsection{Mammals}

During the Holocene 60 mammal species lived where the semiarid region of the southeastern Iberian peninsula lies today. This species community was under intense anthropic modification (Garrido-García, 2008; Appendix C), and the biology and degree of association with semi-deserts of the 44 mammal species which currently live in the area are poorly known. Micromammals are a good example: their scarce diversity in the south of the Iberian peninsula and their frequent association with riparian, agrarian or urban habitats account for the fact that only three native species (Apodemus sylvaticus, Microtus duodecimcostatus and Eliomys quercinus) and three non-native species (Crocidura russula, Suncus etruscus, Mus spretus) have been recorded in semi-deserts (Appendix C, Faus, 1993; García et al., 1987; Garrido-García and Nogueras, 2003; Garrido-García et al., 2009; Palomo et al., 2007; Vericad et al., 1975). Actually, even such a reduced list may overestimate the micromammal fauna in some parts for three reasons: i) nearly all the records are based on Barn owl (Tyto alba) pellets collected from perching sites in semi-arid irrigated field ecotones and most of the species' prey come from cultivated fields (Martínez and Zuberogoitia, 2004); ii) fruit and seed production in these ecosystems is too low to support large rodent populations, and seed and fruit eating rodents are affected negatively (A. sylvaticus, M. spretus), as happens with wintering passerines too (HernándezGil et al., 1995; Hódar, 1993); and iii) the interaction between the environmental heterogeneity of deserts and specific ecological needs causes each taxon to appear in a small fraction of the local fauna and, in turn, local faunas consist of a small fraction of the regional fauna (Kelt et al., 1996).

The impoverished fauna of the Iberian southeast, without desert species, would strengthen these tendencies. Even local ecological situations may arise to which no species may adapt. Research conducted in 2008 on a range of habitats of Hoya de Guadix (Garrido-García, unpubl. results) found some such examples: no micromammal was captured, even if the research took place at the peak of the biological activity (March) and relied on the most efficient trapping method (Garrido-García et al., 2009; Gurnell and Flowerdew, 1982). Based on signs and tracks, only small populations of $\mathrm{M}$. duodecimcostatus were recorded associated with therophytic meadows of smooth, silt substrate slopes and plains. These records were later confirmed based on 32 faecal depositions of Vulpes vulpes collected in the area. These depositions contained only remains of this micromammal and rabbits. In nearby Hoya de Baza, Sherman traps and searches for signs and traces gave the same results. However, samplings with insect pitfall traps captured one M. spretus, while S. etruscus are often captured (Hódar and Sánchez Piñero, pers. comm.).

The data available on the remaining mammals of the semi-arid ombroclimate of the Iberian southeast show three relationships with the semi-desert that can be evidenced as three groups (Appendix C). Group 1 involves forest or river species which occur in semi-arid areas only occasionally (Erinaceus europaeus, Sus scrofa, Lutra lutra, Mustela putorius and Genetta genetta) (Barea et al., 2004; Garrido-García and Nogueras, 2003; Palomo et al., 2007; Wilson and Mittermeier, 2009).

Group 2 uses semi-arid ecosystems as shelter and breeding sites, but feeds in cultivated land and in river habitats. The most diverse and best known of Chiroptera are the troglophyles (Rhinolophidae, Myotis sp., Miniopterus schreibersii) (Garrido-García and Nogueras, 2003; Guardiola et al., 1991; Ibáñez et al., 2005). Leaving aside Myotis daubentonii and Myotis capaccinii, which specialize in aquatic preys (Palomo et al., 2007), and the winter colonies, which select their shelters according to microclimates instead of the surrounding ecology (Ransome, 1990), Chiroptera occur less frequently than in nearby regions. The few breeding colonies monitored (Rhinolophidae, Myotis blythii, M. schreibersii) use semidesert cavities near irrigated land or near river habitats. The remaining records hint either migration pauses between breeding and winter shelters or groups of males in suboptimal habitats during the breeding season (Ransome, 1990). These Chiroptera have a limited capacity to exploit semi-deserts. This is due to their foraging strategies, which are excellent for hunting in forests or shrubland (foliage-gleaners, fly catchers) but not in open habitats or, in the case of M. schreibersii, to their wing morphology, which allows great flight capacity (fast hawking) and hunting at night in the most productive habitats (forests, river valleys) (Horacek et al., 2000). Research of the diet of a group of Myotis myotis males showed that this species does not prey in semi-deserts but in irrigated land and mesic habitats (Garrido-García, 1997). This group includes non-troglophyle bats too: Pipistrellus pygmaeus, which specializes in aquatic diptera, Pipistrellus kuhlii, whose records in the region are in forests, irrigated land and wetlands, and Tadarida teniotis, another fast hawking (Garrido-García and Nogueras, 2003; Palomo et al., 2007). The best known example among carnivores is Meles meles: it feeds on fruit and insects in irrigated farmland and in mesic habitats, but dwells in semi-deserts (Rodríguez and Delibes, 1992). Based on the considerable trophic overlapping with badgers in nearby areas, Martes foina may behave similarly (Barea and Ballesteros, 1999).

Group 3 comprehends species that have adapted to semi-arid ecosystems. Among Chiroptera, slow hawkings prevail (Hypsugo savii, Eptesicus isabellinus). These benefit from their low specialization, exploit all the habitats available and are the dominant group in other transitional areas between Eurasian forests and semi-deserts (Horacek et al., 2000). Still, the most frequent species is Plecotus austriacus, a highly adaptive species that hunts in a variety of habitats as a surface forager (soil/foliage gleaner) and as an aerial hunter. As to the terrestrial mastofauna, only four herbivores (Capra pyrenaica, Lepus granatensis, Oryctolagus cuniculus and Ammotragus lervia, a Saharan ungulate introduced in the region in 1970s) and two carnivores (V. vulpes and Felis sylvestris) can be added to the six micromammal species above (GarridoGarcía and Nogueras, 2003; Palomo et al., 2007; Serrano et al., 2002). Atelerix algirus is a special case: while it has been associated to shrubland and cultivated land in the literature (Palomo et al., 2007), it also dwells in semi-deserts (Garrido-García, unpubl. results). 
Finally, it is remarkable how the role of Carnivora has changed recently due to the sharp decrease in the rabbit population over the past 50 years (Palomo et al., 2007). Such an ecological catastrophe must not only have proved decisive in the extinction of the most specialized predator in these semi-arid areas (Lynx pardina) (Garrido-García, 2008), but it must also have thrown away the mesocarnivores whose diet relies largely on rabbits (Mustela putorius, Meles meles, M. foina) (Barea and Ballesteros, 1999). Before this decrease, such species could include semi-arid habitats in their trophic strategies, at least seasonally, thanks to the certainty of the abundance of rabbits, instead of relying on them as shelters or avoiding them, as happens today.

This description lays emphasis on the major features of the vertebrates of the Iberian southeast: they are species evolved in non-eremic ecosystems whose communities have undergone, like the rest of the Mediterranean biota, heavy anthropic modification (Blondel and Aronson, 1999). The difference is that, in the Iberian southeast, this modification resulted in severe desertification that meant another crucial selection stage. Species relied on their adaptability to exploit semi-deserts (Group 3), using them as shelter (Group 2), avoiding them (Group 1) or becoming extinguished when confronting this stage. The latter three types of response and the recent origin of these semi-arid habitats explain the major differences with older eremic habitats, like SaharoSindhic ones (Agustí and Antón, 2002; Kelt et al., 1996). Such differences can be summarised as structural impoverishment and simplification, and the greater importance of invading species. Their effects become evident from the comparison between the cenograms of the mastofauna of the semi-arid areas of the Iberian southeast and those of the nearest semi-deserts (Fig. 1): i) the Iberian community is poorer ( 8 vs. 16 species in the African community); ii) the separation between large and small species is greater in the Iberian community as a result of the gap left unfilled by typically North African species that did not occupy the Iberian southeast (Jaculus, Psammomys, Ctenodactylus, Histryx, Gazella); and iii) the Iberian community displays the effects of its major anthropic modification, for example a rodent community of which $25 \%$ are non-native species and the complete extinction of large herbivores. The latter was recently rebuilt reintroducing C. pyrenaica and importing Ammotragus lervia.

This description of the mastofauna is based on separate research by one of the authors (JAG-G). Further research is necessary for proper assessment of: i) the degree of integration in semi-arid habitats by the taxons of the regional mastofauna; ii) the resources which they obtain from these habitats; and iii) the ecological and ethological differences between mastofauna populations and their counterparts of mesic habitats. To this purpose, the methods used for mesic mammals must be used in all semidesert habitats (Barea and Ballesteros, 1999; Garrido-García, 1997, 2008), and the results obtained must be supported by analysis of the availability of trophic resources, especially insects, fruits and seeds (Hódar, 1993).

Overall, the vertebrate fauna of the semi-arid southeast of the Iberian peninsula shows the following specific features: i) its taxonomic composition diverges markedly from that of the semiarid and desertic Maghreb; ii) the lack of desert species sensu stricto suggests that some of the ecological niches available may remain unoccupied; this would explain the arrival of invading species, both reptiles (Mediterranean house gecko Hemidactylus turcicus) and, especially, mammals (Soricidae, Muridae, Atelerix algirus, A. lervia). To a large extent, the success of these invasions is just one more aspect of the intense anthropic effects on the fauna; iii) a large part of the vertebrates dwelling in the semi-arid region of the Iberian southeast exploit the semi-deserts only marginally. Some species in fact rely on the riparian habitats that cut across the semi-deserts (L. lutra, M. putorius, S. scrofa, E. orbicularis). Most vertebrates have eventually become associated with farmland and their irrigation systems and can thus be viewed as anthrophylous species. For example, P. perezi and B. bufo rely almost exclusively on man-made water bodies, $M$. meles and $M$. foina feed mainly on the fruit of orchards, and nearly all troglophylous bats build their colonies next to the irrigated land where they hunt; iv) the vertebrate fauna of these semi-arid areas comprehends a small fraction of the species of the Iberian southeast, namely the Palaearctic, European or Mediterranean vertebrates that succeeded to adapt to the ecological limitations of aridity. By contrast,
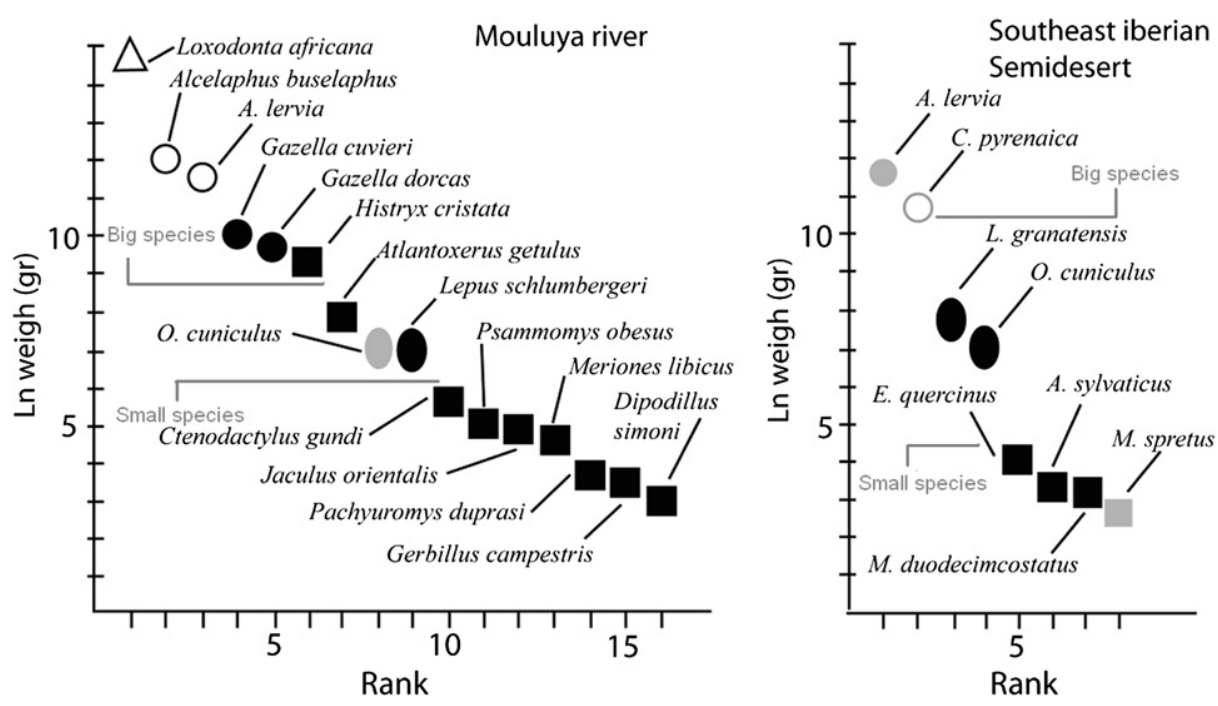

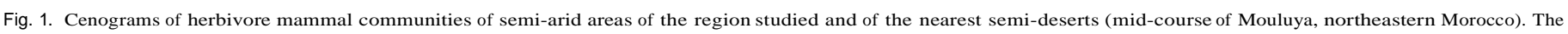

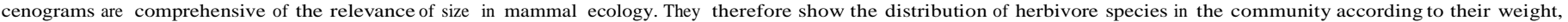

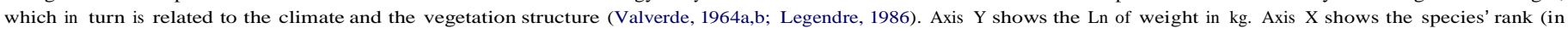

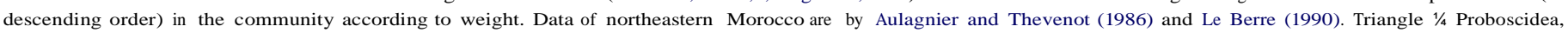

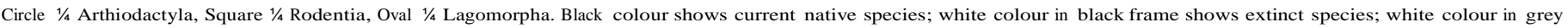
frame shows extinct species which were later reintroduced; grey colour shows allochthonous species. 
the species that can only exploit mesic forests and shrubland mountain are missing.

Some of the former adaptations are reviewed in Section 3.

\section{Ecological mechanisms of adaptation and organization}

\subsection{Amphibians and the unpredictability of breeding sites}

Most amphibian species depend on the availability of adequate water bodies for reproduction. The patchy distribution of many species is associated with the scattered distribution of wetlands, particularly in arid regions where suitable breeding sites are sparse (Dayton and Fidgeral, 2006).

In desert areas, natural aquatic habitats are scarce and consist mainly in temporary waters of unpredictable filling and desiccation. The hydroperiod (duration of water) of these habitats influences the duration and the success of the larval phase in amphibians. Thus, desert species are usually explosive breeders which use temporary or ephemeral breeding sites following sudden rainfall (Low, 1976). In these habitats, only species with short larval periods can complete their development. Their populations may fluctuate in size largely due to the unpredictability of the breeding habitats, commonly supporting years without reproduction or episodes of high larval or clutch mortality due to early desiccation (Mayhew, 1965; Newman, 1987; Tevis, 1966). Additionally, desert anurans are characterized by big male chorus activity, which helps other males and females to locate available breeding sites (Sullivan, 1982). The stochasticity of these habitats favours a negative selection of site philopatry and a greater selection for continued individual dispersal (Chan and Zamudio, 2009).

In semi-arid southeastern Spain, the availability of natural habitats as breeding sites is limited mainly to episodic pools of unpredictable duration following heavy rains. The steadiness of these water bodies varies according to their substrate and their location, but they often dry up fast. Other aquatic habitats associated to human activities, mainly irrigation pools and troughs, are frequently reported as amphibian breeding sites where water may remain for long seasonal periods or even permanently (GonzálezMiras et al., 2003; Torralva et al., 2005). The availability of these artificial habitats explains the wide occurrence of a mainly aquatic species, P. perezi, or even of B. bufo, which usually breeds in permanent waters.

By contrast, in natural habitats, where pond formation and hydroperiods are uncertain or unpredictable, only species supporting high larval mortalities or with short larval development may maintain long-term stable populations. Desert species are reported to be missing, and the closest to arid specialized species is precisely the most abundant amphibian in these natural habitats, $B$. calamita. A fast larval development is an advantage for amphibians in semi-arid zones. Such is typically the case with desert Scaphiopus tadpoles, which may develop as fast as in nine days (Newman, 1987). B. calamita's larval period ranges from 1 to 2 months (Díaz-Paniagua et al., 2005), and is the species of shortest larval period in Europe. This species thus has a higher probability to breed successfully in small and short duration pools than species with longer larval development.

Other species in the area, like P. punctatus and D. jeanneae, may develop in similar periods, but their capacity to colonize semi-arid zones must be constrained by other features, because they are not as abundant as B. calamita. Even though B. calamita has a thicker dermis than the former species, a thick dermis is not considered to provide substantial differences in water loss among amphibian species (Wells, 2007) and, therefore, this species should have other advantageous behavioural mechanisms compared to other species. After Oromí et al. (2010), B. calamita adults move exclusively at night following rain and are inactive in the absence of precipitation. They can move over long distances of $3 e 4 \mathrm{~km}$ (maximum $0.5 \mathrm{~km} /$ day). This allows them to move from pond to pond when their breeding sites are close to desiccation (Miaud et al., 2000).

The capacity of moving to new sites is an advantage in arid zones, where patchy populations are common, with dispersal among patches compensating local extinctions and favouring the maintenance of the population in a large patchy habitat (Bradford et al., 2003). Sudden desiccation of breeding pools frequently results in unsuccessful breeding episodes, with high mortality of larvae or clutches. Subsequent breeding attempts during the same season may eventually result in some annual reproductive output. This mortality pattern has been observed in B. calamita in Almería pools, where three different periods of clutches were recorded from autumn to winter after occasional heavy rain that filled breeding sites. Intermittent ponds dried up before the eggs of the clutches could hatch or complete embryo development (recorded twice for more than 30 clutches in a pond). Still, metamorphics (revealing successful reproduction) were recorded from clutches laid in earlier episodes of pond filling (Guirado-Romero and DíazPaniagua, unpubl. results). Actually, although explosive reproductive behaviour is recorded after heavy rain, in Almería pools adult males have been observed to remain near ponds waiting for the arrival of females on subsequent occasions following rainy days in order to extend their breeding period (Guirado-Romero and Díaz-Paniagua, 1991).

Thus, B. calamita is the species best adapted to colonization of semi-arid habitats among the ones recorded in southeastern Spain for its short larval period, repetitive breeding to compensate high egg and tadpole mortalities, and the ability to disperse to different breeding sites. This profile cannot be found in the other species with lower abundance in this area.

\subsection{Generalist reptiles under restrictive ambient temperature and water availability}

Ecologically, the current reptile fauna in the region is generalist, and the sixteen native species are typically Mediterranean as regards habitat use. In support of this statement, three out of the ten species from the Iberian southeast which are also found in northwestern Africa (Psammodromus algirus, Coronella girondica and Macroprotodon brevis) dwell in mesic habitats of northwestern Africa, not in semi-deserts. This may be because of a much richer reptile fauna in northwestern Africa, which are also well adapted to aridity and preclude, perhaps by competition, Mediterranean species to dwell in these arid environments.

For the reptiles in the southeast of the Iberian peninsula, the low average annual rainfall (extreme values of $170 \mathrm{~mm}$ in Cabo de Gata, Almería province) represents the extreme of their tolerance for this environmental variable throughout their Iberian range. In fact, for some of them, it does throughout their entire range. Most of these non-desert species withstand the semi-arid conditions of their habitats by ecological mechanisms, for example going deeper into the region through oasis-like habitats, following river courses and their riparian vegetation (Mauremys leprosa, Rhinechis scalaris and M. brevis; see also sections on Mammals and Birds), or limiting themselves to isolated spots in northern slopes or at some altitude and, therefore, having more mesic conditions (B. cinereus, C. girondica and Vipera latastei). The remaining non-desert species occupy every biotope in the region, including the harshest ones, like rock outcrops or bare soil. Exposure to temperatures above the critical thermal maxima would however be lethal for reptiles. Therefore, some use a behavioural mechanism, aestivation, to adapt themselves to the high summer temperatures. Although there is no compelling information, empirical evidence shows that for large- 
bodied species (e.g. colubrids) the number of daily records drops during the hardest aestival period in the region (July and the first half of August, because of restrictive conditions of environmental temperature and water availability). This decrease suggests less activity (Feriche, 1998). The records at midday just disappear, because species display a bimodal daily activity pattern (Pianka, 1986). The observation of the tendency towards aestivation only in snakes is likely to be due to their limbless morphology, which couples body temperature more closely to that of the substratum than the morphology of lizards can do (Lillywhite, 1987).

Temperature also has a major influence on reproductive cycles in reptiles, especially in temperate environments. The climatic conditions of semi-arid southeastern Iberia, with a short, cold season, also offer ectothermic vertebrates an extended annual period of activity and reproduction. Therefore, in this Iberian region, the only two western European reptiles whose males exhibit vernal spermatogenesis (Malpolon monspessulanus and Hemorrhois hippocrepis; 3.6\% of the western European fauna) are both widespread and abundant. These two species produce spermatozoa in spring, just before mating, whereas the other western European species exhibit aestival spermatogenesis. Species with vernal cycles are restricted to warm regions, where a longer activity period allows completion of the reproductive cycle of both sexes (spermatogenesis, vitellogenesis, mating, ovogenesis, laying and incubation) within a calendar year. The two abovementioned colubrid species find these environmental conditions in the Iberian southeast (Feriche et al., 2008). The extended annual activity period in the region also allows the largest lizard in Iberia, T. lepidus, to start reproduction two months earlier and breed twice within a calendar year instead of once, as is the case in other regions of the Iberian peninsula (Mateo and Castanet, 1994). The annual activity period of some reptiles in the semi-arid southeastern Iberian peninsula seems to be currently extending in response to global warming, as has been recently demonstrated for M. monspessulanus (Moreno-Rueda et al., 2009).

\subsection{Predation pressure and breeding strategies}

Semi-arid zone ground-breeding passerines were reported in the 1990s to sustain high predation rates (60e90\% according to species, year and location; Suárez et al., 1993, 2009; Yanes and Suárez, 1995, 1996a). However, the effect of such rates on the breeding strategies and population dynamics is poorly explained and the small amount of data available are mainly of larks in the semi-arid southeast of the Iberian peninsula.

The effect of predation on the breeding strategies of larks in southeastern Spain has been compared with that of other nonground nesting species of Iberia. After correction of phylogenetic inertia, only the length of the nestling period proved significant among the factors considered (clutch number and size, egg size, hatching asynchrony, etc.; Yanes and Suárez, 1997). The growth in the body mass of nestlings is close to their physiological maximum (Shkedy and Safriel, 1992), but the tarsus growth rate is even higher than that of the body mass (Suárez et al., 2009). The latter has been interpreted as a strategy for reduction of the nestling period duration, so nestlings can leave the nest 7e9 days after hatching. Other reproductive factors may also affect the length of the nesting period and, thus, nest predation risk. For example, low clutch size and high asynchrony reduce total duration, although the effect of such factors on the annual breeding success of these multi-brooded species is very low even with high predation rates (Yanes and Suárez, 1996b).

All the major nest predators for these species are generalist predators (mainly canids, but also snakes, lacertids, mustelids and even rodents, Yanes and Suárez,1996a) and vary widely between locations and years (Yanes and Suárez, 1996a; Suárez et al., 2009). For a fox, predation of a nest during brooding means $1 \mathrm{e} 2 \%$ of its daily food requirement (Yanes and Suárez, 1996a). It is therefore unlikely that foxes will specialize on this prey type. Rather, this is incidental predation and can have an impact on these species' conservation at high predation rates, as it is density-independent.

This is a major issue in nature reserve management. Yanes and Suárez (1996a) showed in a nature reserve in Cabo de Gata (Almería) that lack of control on predators (mainly foxes and feral dogs) along with hunting bans resulted in a sharp increase in the population of rabbits and of the former predators, the rabbit being their main prey. Incidental predation increased nest mortality for Ch. duponti and other steppe passerines above the level estimated for population viability. As a result, the protected species decreased sharply in that area. At least the most representative species, Ch. duponti, continues to decrease today: the 1988 population, which in all certainty amounted to at least 46 singing males, plummeted from three to four singing males in 2008 (Suárez et al., 2009). Indirect evidence, like the ratio of nests found per search time, also showed that at least the other lark species had decreased sharply in density too (Manrique and Suárez, unpubl. results). Nonetheless, the overall decline of the populations of Ch. duponti in southeastern Spain (even in unprotected areas where the increase of incidental predation is not expected) suggests the influence of other factors, like population fragmentation (see Laiolo and Tella, 2006a; Vögeli et al., 2010).

\subsection{Consequences of nest site limitation}

Nest sites are often assumed to be the primary constraint on populations of cavity-nesting birds ( $\mathrm{Li}$ and Martin, 1991). The seemingly abundance of holes in ramblas and natural walls may make such resources appear to be unimportant for population control and the community structure of semi-desert bird species in the study area. However, not all holes are suitable for birds. The holes which birds can use are not only scarce but they also occur in specific, small areas. Nest site limitation has been shown for the European roller Coracias garrulus in the Desert of Tabernas (Almería), where they breed mostly in natural holes in cliffs. A nest box installation program increased the population of rollers by $56 \%$ in four years during which natural holes were still used too (i.e. the population increase was not merely a change in the place of nesting) (Václav et al., 2011).

Nest site limitation may influence the structuring of natural communities either directly or via interspecific interactions (e.g. predation, competition) and obliges bird species to adapt their behaviour to exploit scarce and ephemeral resources.

Avian communities are noticeably more diverse in dry watercourses or ramblas than in shrub-steppes. This is due mainly to the presence of certain troglodyte species (e.g. Falco tinnunculus, Upupa epops, Corvus monedula, O. leucura, C. garrulus, Manrique, 1996, Yanes and Delgado, 2006) whose distribution and abundance is often influenced by the availability of natural cavities (Newton, 1998), since they have a limited excavating capacity. In this scenario, the occurrence of certain species has a major impact on the organization of the community. Casas-Crivillé and Valera (2005) studied the consequences of the excavating activity of the European bee-eater Merops apiaster, a cavity-nesting species typical of arid and semi-arid habitats. They concluded that the bee-eater can be an ecosystem engineer species in semi-arid ecosystems: this and similar species may prove crucial both in abiotic (as a major bioturbating organism) and biotic processes (providing food resources and nesting and roosting sites, and enhancing biodiversity), reinforcing the structure of the community and enhancing more complex food webs. Moreover, the joint effect of 
nest site constraints and high bird density caused by aggregation of holes (e.g. dozens of pairs of Rock sparrows Petronia petronia breeding within a short distance as a result of the excavating activity of bee-eaters, Casas-Crivillé and Valera, 2005) may have additional consequences at the community, population and individual level. Valera et al. (2003) recorded interspecific parasite exchange in a mixed colony of $\mathrm{M}$. apiaster and P. petronia, and stressed that such scenarios are especially suitable for research on apparent competition mediated by shared parasites (e.g. Tompkins et al., 2000).

Certain species have overcome nest site limitation by some species using remarkable behavioural adaptations to new conditions. Exclusively troglodyte species that prefer to nest in tree cavities perform major changes in basic behaviour patterns to exploit their habitats. For example, the Green woodpecker Picus viridis, a species characteristic of thickets and sparse forests, has been recorded to nest in burrows excavated in rambla walls of shrub semi-desert (Soler et al., 1982).

Thus, it is generalist species that exploit semi-arid ecosystems. These species have adapted anatomically or ethologically and can therefore use resources that are scarce and ephemeral in time and in space. They have: i) strong trophic adaptability (V. vulpes); ii) little morphological specialization, which allows them to exploit resources of a variety of habitats (slow hawking bats, P. austriacus); iii) pre-adaptations, which allow them benefit from breeding areas that are not suitable for other species (ephemeral and scattered ponds), such as a short larval period and repetitive breeding to compensate mortality of clutches and larvae (B. calamita); iv) the ability to avoid the least favourable periods by means of behavioural mechanisms (aestivation) while benefitting from the mild winters typical of most of this region (extension of the reproductive period and sporadic activity during winter, T. lepidus); and v) in birds, for example, the intense nest predation that is common in these habitats is avoided by reducing the nestling period duration (by fast growth), or the problems caused by a shortage of nesting sites are solved by behavioural adaptations (P. viridis).

\section{Conservation and management}

Steppic and semi-desert ecosystems are endangered worldwide, many of them for the same reasons, ranging from conversion to arable land to overgrazing or forestry (Laiolo and Tella, 2006b; Sánchez-Zapata et al., 2003). Most of these threats find their origin in the widespread negative view of this type of habitat and the recent changes in the economic possibilities offered by semiarid lands (Suárez et al., 1991, 1996; Yanes and Delgado, 2006). Iberian semi-arid areas and, particularly, the ones of southeastern Spain, are a clear example of such changes and of their consequences. During the first half of the last century, traditional land use in this area included economic exploitation of S. tenacissima and dry cereal farming combined with extensive sheep and goat farming. In some areas, mainly along the ramblas, small orchards of orange, olive and almond groves were cultivated (Suárez et al., 1991, 1996; Yanes and Delgado, 2006).

Starting the second half of the 20th century, exploitation of Stipa and cereal farming became unprofitable. Instead, Agave and Pinus spp. plantations were fostered (similar to current plantations of Opuntia and Eucalyptus trees in pre-desert areas of the Maghreb, Suárez, pers. obs.). The advent of mechanised farming in the 1960s brought about drastic changes. From 1960 to the end of the 1980s the surface devoted to dry cereal farming decreased by one-third, while irrigated land doubled in size and the almond plantations increased almost nine times (Manrique and De Juana, 1991). At that time, the intensification of agriculture was identified as a major threat on the conservation of this ecosystem, and replacement of low intensity dry cereal farming by almond tree plantations and/or irrigated cultivations was suggested to be the most detrimental factor. These changes resulted in a widespread decrease in the population levels of most of the bird species associated with steppic and semi-arid habitats (Manrique and De Juana, 1991). A change in the amphibian fauna in the last century also occurred. The drastic increase in cultivated areas and the abandonment of sheep and goat farming, the latter of which resulted in the regeneration of scrub and loss of ponds and drinking-troughs, caused a decrease in species with low dispersal capacities breeding in natural temporary habitats. By contrast, the construction of irrigation ponds in these areas seems to have benefited amphibians associated with permanent waters (P. perezi). The main management recommendations at that time were to increase the protected surface and to encourage extensive cereal farming (Manrique and De Juana, 1991).

In the 1970s and 1980s the low availability of water prevented land use change and agricultural intensification in many places. Therefore, large rather unprofitable areas were common (abandoned cultivation grounds, Stipa fields). By contrast, plastic farming increased exponentially in those areas where water was available (mainly underground). In this regard, two phases can be distinguished: i) small-scale privately funded plastic farming; and ii) settlement of large agrifood companies at the end of the last century, which had a large impact on the area. The simultaneous growth of urban areas and leisure tourism starting at the turn of the century altered large extensions of semi-arid landscape. The changes produced by the latter phase can be shown by the increased per capita income in Almería over the last few years, which climbed to top positions after decades of ranking as the poorest province in Spain. Consequently, southern Spanish shrubsteppes have decreased considerably more than other Spanish steppes in the last few decades (Laiolo and Tella, 2006a,b; Suárez, 2010).

Two recent threats on Spanish steppes and semi-arid ecosystems can be added: i) industrial activity like mining, rubbish dumps, and wind industry reduce the range of steppes and semideserts and create new disturbances to the ecosystem (e.g. increased predation or casualties at wind turbines, Laiolo and Tella, 2006a,b); and ii) recent large-scale irrigation plans. The increased water availability resulting from new desalination plants and transfer from other hydrographic basins will alter land use dramatically, with an increase in land devoted to plastic farming, urbanization and leisure tourism. This may reverse the abandonment of marginal-low productivity areas documented by Laiolo and Tella (2006a,b). Habitat loss at a large scale would have very negative consequences on the distribution, size, persistence (Driscoll, 2004) and communication systems (Laiolo and Tella, 2005) of natural populations.

Other threats that could act locally are the abandonment of the already scarce sheep farming, the occurrence of invasive species (Pleguezuelos et al., 2002), the destruction of cliffs and ramblas in favour of modern infrastructures, human vs. wild vertebrates competence for water and the increase in traffic casualties due to the development of the road network.

In general, today's threats on the conservation of southeastern Spanish semi-arid areas are very different from those on the preSaharan areas of the Maghreb, where droughts, overgrazing, fumigation against locust plagues or plantations of Opuntia and Eucalyptus trees are the major menaces.

\subsection{Management recommendations}

Conservation of steppe and semi-arid ecosystems in Spain requires major management measures, the most important being: i) an increase in protected habitat and a network of connected 
steppelands and semi-deserts encompassing badlands in the provinces of Jaén, Granada, Murcia and Almería (Laiolo and Tella, 2006b). Only 8\% (4000 has.) of the most important area covered by semi-deserts in Almería province were legally protected in the early 1990s (Manrique and De Juana, 1991). Conservation efforts supporting key species like Ch. duponti could protect a large community of other threatened birds (Laiolo and Tella, 2006a,b; Suárez, 2010); ii) proper regulation of human activity. Illegal activities (changes in land use, illegal greenhouses, over exploitation of underground water, urbanization) are often passively accepted or ignored by the administrations. Rural poverty may have been argued as a justification in the past, but this argument is less and less valid; iii) a new public view of the ecological value of semiarid habitats. The negative view of the value of this habitat type is widespread and deep-rooted in Spain, both for economic and 'ecological preferences' (Suárez et al., 1991). Effective education, dissemination and compensation measures are needed here; and iv) a better knowledge of how ecosystems work is fundamental for conservation and management purposes. This is particularly the case in semi-arid habitats, which are specially fragile and sensitive. It is important to identify key species and to implement adequate management measures, to alleviate the negative effect of human activity and to avoid undesirable consequences like the ones described above.

\section{Acknowledgements}

We would like to thank Mónica Feriche for help with fieldwork and, F.J. Sánchez Piñero (University of Granada) who supplied the data on micromammals in Hoya de Baza (Granada). Leanne Bartley corrected the English. We are indebted to two anonymous referees for valuable comments.

\section{Appendix. Supplementary data}

Supplementary data associated with this article can be found, in the online version, at doi:10.1016/j.jaridenv.2011.05.004.

\section{References}

Agustí, J., Antón, M., 2002. Mammoths, Sabertooths and Hominids. 65 million years of Mammalian Evolution in Europe. Columbia Univ. Press, New York.

Arrébola, J.R., Garrido, J.A., Bertrand, M., 2000. Distribución, ecología y origen de las poblaciones de Vitrina pellucida y Cepaea nemoralis (Gastropoda, Stylommatophora) en las cordilleras Béticas orientales (Andalucía, España). Pirineos 155, $91 \mathrm{e} 109$.

Aulagnier, S., Thevenot, M., 1986. Catalogue des mammiféres sauvages du Maroc. Travaux de l'Institut Scientifique-Serie Zoologie 41, 1 e164.

Bailón, S., 1991. Amphibiens et reptiles du Pliocène et du Quaternaire de France et d'Espagne: mise en place et évolution des faunes. vol. 2. Thèse Doctorale. Université de Paris VII: Paris.

Barbadillo, L.J., García-París, M., Sanchiz, B., 1997. Orígenes y relaciones evolutivas de la her petofauna ibérica. In: Pleguezuelos, J.M. (Ed.), Distribución y Biogeografía de los anfibios y reptiles en España y Portugal. Ed. Univ. Granada, Granada, pp. 47e100.

Barea, J.M., Ballesteros, E., 1999. Carnívoros Ibéricos. COBA, Granada.

Barea, J.M., Ballesteros, E., Moleón, M., Gil -Sánchez, J.M., Virgós, E., Chirosa, M., 2004. Distribución de los mamíferos carnívoros en la provincia de Granada. Acta Granatense 3, 43e54.

Bertrand, M., Sánchez-Viciana, J.R., 2006. L 'irrigation du territoire de Guadix, Les grandes acequias de Sierra Nevada: l'Acequia de la Sierra. In: Cressier, P. (Ed.), La maîtrise de l'eau en Al-Andalus. Paysages, pratiques et techniques. Casa de Velazquez, Madrid, pp. 1e49.

Blondel, J., Aronson, J., 1999. Biology and Wildlife of the Mediterranean Region. Oxford University Press, Oxford.

Blondel, J., 1962. Donnés écologiques sur l'avifaune des Monts des Ksours (Sahara septentrional). Terre et Vie 16, 209e251.

Bons, J., Geniez, P., 1996. Amphibiens et reptiles du Maroc (Sahara Occidental compris). Atlas bioéographique. Asociación Herpetológica Española, Barcelona.

Bradford, D.F., Neale, A.C., Nash, M.S., Sada, D.W., Jaeger, J.R., 2003. Habitat patch occupancy by toads (Bufo punctatus) in a naturally fragmented desert landscape. Ecology 84, 1012 e1023.
Burjach, F., Giralt, S., Riera, S., Roca, J.R., Julià, R., 1996. Evolución paleoclimática durante el último ciclo glaciar en la vertiente mediterránea de la Península Ibérica. Notas de Geografía Física 25, 21 e39.

Capel, J.J., 1990. Climatología de Almería. Instituto de Estudios Almerienses, Almería.

Casas-Crivillé, A., Valera, F., 2005. The European Bee-eater (Merops apiaster) as an ecosystem engineer in arid environments. Journal of Arid Environments 60, 227 e238.

Chan, L.M., Zamudio, K.R., 2009. Population differentiation of temperate amphibians in unpredictable environments. Molecular Ecology 18, 3185e3200.

Charco, J., 1999. El bosque mediterráneo en el Norte de África. Biodiversidad y lucha contra la desertificación. AECI, Madrid.

Costa, M., Morla, C., Sainz, H., 1998. Los bosques ibéricos. Una Interpretación Geobotánica. Planeta, Barcelona.

Dayton, G.H., Fidgeral, L.A., 2006. Habitat suitability models for desert amphibians. Biological Conservation 132, 40e49.

De Juana, E., 2006. Aves raras de España. Un catálogo de las especies de presentación ocasional. Lynx Edicions, Barcelona.

Díaz-Paniagua, C., Gómez Rodríguez, C., Portheault, A., de Vries, W., 2005. Los anfibios de Doñana. Serie Técnica. Ministerio Medio Ambiente. OAPN, Madrid.

Driscoll, D.A., 2004. Extinction and outbreaks accompany fragmentation of a reptile community. Ecological Applications 14, 220 240.

Faus, F.V., 1993. La problemática de los roedores comensales en la vega baja del río Segura (Alicante). Mediterránea Serie Biológica 14, 79e102.

Feriche, M., Pleguezuelos, J.M., Santos, X., 2008. Reproductive ecology of the Montpellier snake, Malpolon monspessulanus, and comparison with other sympatric colubrids in the Iberian Peninsula. Copeia 2008, 279e285.

Feriche, M., 1998. Ecología de la reproducción de los Colúbridos del sureste de la Península Ibérica. Tesis doctoral. Univ. Granada, Granada.

García, L., Oña, J.A., Salas, G., Román, F.J., 1987. Estudio estacional de Tyto alba en un medio árido casi antropógeno de los alrededores de Almería. Boletín del Instituto de Estudios Almerienses 1, 113 e129.

García, J.T., Suárez, F., Garza, V., Hernández, J., Oñate, J.J., Hervás, I., Calero, M., García de la Morena, E., 2008a. Assessing the distribution, habitat, and population size of the threatened Dupont's lark Chersophilus duponti in Morocco: lessons for conservation. Oryx 42, 592e599.

García, J.T., Suárez, F., Garza, V., Calero-Riestra, M., Hernández, J., Pérez-Tris, J. 2008b. Genetic and phenotypic variation among geographically isolated populations of the globally threatened Dupont's lark Chersophilus duponti. Molecular Phylogenetics and Evolution 46, 237 e251.

Garrido-García, J.A., Nogueras, J., 2003. La mastozoofauna de la cuenca del Río Fardes (SE de la península Ibérica): atlas provisional de distribución. Zoologica Baetica 13/14, 9e36.

Garrido-García, J.A., Pérez-Aranda, D., Pardávila, X., Carro, F., Soriguer, R.C., 2009. Nuevas citas de micromamíferos en Andalucía Oriental: herramientas de muestreo y corología. Galemys 21, 27e49.

Garrido-García, J.A., 1997. La alimentación de Myotis myotis (Chiroptera, Vespertilionidae) en la cuenca del río Guadix (Sureste de España). Doñana, Acta Vertebrata 24, 27e38.

Garrido-García, J.A., 2008. Las comunidades de mamíferos del sureste de la Península Ibérica: elementos para un análisis histórico. Galemys 20, 3e46.

González-Miras, E., Valero, J., Nevado, J.C., 2003. Estado de conservación de enclaves acuáticos en la Sierra de los Filabres (Almería): Implicaciones para los anfibios. In: Paracuellos, M. (Ed.), Ecología, manejo y conservación de los humedales. Instituto Estudios Almerienses, Almería, pp. 151e161.

Guardiola, A., Fernández, M.P., González, G., 1991. Los quirópteros de la Región de Murcia. Status, distribución y conservación. Agencia Regional para el Medio Ambiente y la Naturaleza. C. A. Murcia. Unpublished report.

Guillaumet, A., Crochet, P.A., Godelle, B., 2004. Phenotypic variation in Galerida larks in Morocco: the role of history and natural selection. Molecular Ecology 14, 3809 e3821.

Guillaumet, A., Pons, J.M., Godelle, B., Crochet, P.A., 2006. History of the Crested Lark in the Mediterranean region as revealed by mtDNA sequences and morphology. Molecular Phylogenetics and Evolution 39, 645e656.

Guirado-Romero, N., Díaz-Paniagua, C., 1991. Características de un coro de Sapos Corredores (Bufo calamita) en el Sureste de España. Doñana, Acta Vertebrata 18, $51 e 62$.

Gurnell, J., Flowerdew, J.R., 1982. Live trapping small mammals. A practical guide. Occasional Publications of the Mammal Society 3, 1e39. London.

Hernández, F., Pelayo, E., 1987. Sobre comunidades de aves esteparias en planicies del valle medio del Ebro. In: Actas del I Congreso Internacional de Aves Esteparias. Junta de Castilla y León, pp. 379e393.

Hernández-Gil, V., Esteve, M.A., Ramírez, L., 1995. Ecología de las estepas de la Región de Murcia. Estructura y dinámica de sus comunidades orníticas. Univ. de Murcia, Murcia.

Hódar, J.A., 1993. Relaciones tróficas entre los paseriformes insectívoros en dos zonas semiáridas del sureste peninsular. $\mathrm{PhD}$ thesis. Universidad de Granada. Granada.

Horacek, I., Hanák, V., Gaisler, J., 2000. Bats of the Paleartic region: a taxonomic and biogeographical review. In: Woloszyn, W. (Ed.), Proceedings of the VIIIth EBRS, vol. 1. CIC-ISEZ-PAN, Brno, pp. 11 e157.

Ibáñez, C., Migens, E., Fijo, A., Quetglas, J., Garrido-García, J.A., Nogueras, J., 2005. Seguimiento y conservación de refugios de murciélagos cavernícolas en Andalucía. (Almería, Cádiz, Granada, Huelva, Málaga y Sevilla). Memoria Final. EBD/CSIC-Junta de Andalucía. Unpublished report . 
Kelt, D.A., Brown, J.H., Heske, E.J., Marquet, P.A., Morton, S.R., Reid, J.R.W., Rogovin, K.A., Shenbrot, G., 1996. Community structure of desert small mammals: comparisons across four continents. Ecology 77, 746e761.

Laiolo, P., Tella, J.L., 2005. Habitat fragmentation affects culture transmission: patterns of song matching in Dupont's lark. Journal of Applied Ecology 42, 1183 e1193.

Laiolo, P., Tella, J.L., 2006a. Landscape bioacoustics: combining landscape ecology and call variability to detect the effects of habitat fragmentation on population structure. Ecology 87, 1203e1214.

Laiolo, P., Tella, J.L., 2006b. Fate of unproductive and unattractive habitats: recent changes in Iberian steppes and their effects on endangered avifauna. Environmental Conservation 33, $223 \mathbf{e} 232$.

Le Berre, M., 1990. Faune du Sahara. In: Mammifères, vol. 2. Ed. Raymond Chabaud, Paris.

Legendre, S., 1986. Análisis of mammalian communities from the late Eocene and Oligocene of southern France. Paleovertebrata 16, 191 e212.

Li, P., Martin, T.E., 1991. Nest-site selection and nesting success of cavity-nesting birds in high elevation forest drainages. Auk 108, 405e418.

Lillywhite, H.B., 1987. Temperature, energetics and physiological ecology. In: Seigel, R.A., Collins, J.T., Novak, S.S. (Eds.), Snakes: Ecology and Evolutionary Biology. Macmillan, Canadá, Toronto, pp. 422e477.

Low, B.S., 1976. The evolution of amphibian life histories in the desert. In: Goodal, D.W. (Ed.), Evolution of Desert Biota. Univ. Texas Press, Austin, pp. 149e195.

Manrique, J., De Juana, E., 1991. Land-use changes and the conservation of dry grassland birds in Spain: a case study of Almería province. In: Goriup, P.D., Batten, L.A., Norton, J.A. (Eds.), The Conservation of Lowland Dry Grassland Birds in Europe. Joint Nature Conservation Committee, Newbury, UK, pp. 49e58.

Manrique, J., 1996. Corología y ecogeografía de las aves nidificantes en la provincia de Almería (SE Ibérico). PhD thesis. Universidad de Granada. Granada.

Martí, R., del Moral, J.C. (Eds.), 2003. Atlas de las aves reproductoras de España. SEO/ Birdlife-MMA.

Martínez, J.A., Zuberogoitia, I., 2004. Habitat preferences and causes of population decline for barn owls Tyto alba: a multiescale approach. Ardeola 51, 303e314.

Mateo, J.A., Castanet, J., 1994. Reproductive strategies in three Spanish populations of the ocellated lizard, Lacerta lepida (Sauria, Lacertidae). Acta Oecologica 15, $215 e 229$.

Mayhew, W.W., 1965. Adaptations of the amphibian Scaphiopus couchi to desert conditions. American Midland Naturalist 74, 95e109.

Miaud, C., Sanuy, D., Avrillier, J.N., 2000. Terrestrial movements of the natterjack toad Bufo calamita (Amphibia, Anura) in a semi-arid, agricultural landscape. Amphibia-Reptilia 21, 357e369.

Molina, B., Prieta, J., Lorenzo, J.A., López-Jurado, C., 2010. Noticiario Ornitológico. Ardeola 57, 517e549.

Moreno-Rueda, G., Pleguezuelos, J.M., Alaminos, E., 2009. Climate warming and activity period extension in reptiles: evidence from the Mediterranean snake Malpolon monspessulanus. Climatic Change 92, 235 e242.

Navarro, F.B., Simón, E., Lorite, J., Valle, F., 1998. Relación “clima-vegetación” durante la Edad del Cobre-Bronce y la actualidad en la depresión de Guadix-Baza basado en análisis antracológicos. Colloques Phytosociologiques XXVIII, pp. 1042 e1052.

Newman, R.A., 1987. Effects of density and predation on Scaphiopus couchi tadpoles in desert ponds. Oecologia 71, 301e307.

Newton, I., 1998. Population Limitation in Birds. Academic Press, London.

Oromí, N., Sanuy, D., Sinsch, U., 2010. Thermal ecology of natterjack toads (Bufo calamita) in a semiarid landscape. Journal of Thermal Biology 35, 34e 40 .

Palomo, L.J., Gisbert, J., Blanco, J.C., 2007. Atlas y Libro Rojo de los mamíferos terestres de España. MMA-TRAGSA-SECEMU-SECEM, Madrid.

Pantaleón-Cano, J., Yll, E.I., Pérez-Obiol, R., Roure, J.M., 2003. Palynological evidence for vegetational history in semi-arid areas of the Western Mediterranean (Almería, Spain). The Holocene 13, 109e119.

Pianka, E.R., 1986. Ecology and Natural History of Desert Lizards. Princeton University Press, Princeton, New Jersey.

Pleguezuelos, J.M., Márquez, R., Lizana, M. (Eds.), 2002. Atlas y Libro Rojo de los anfibios y reptiles de España. AHE-MMA, Madrid.

Pleguezuelos, J.M., 1992. Avifauna nidificante de las sierras subbéticas orientales y depresiones de Guadix, Baza y Granada. Su cartografiado. Universidad de Granada e Agencia de Medio Ambiente Junta de Andalucía.

Quézel, P., Médail, F., 2003. Écologie et biogéographie des forêts du bassin méditerranéen. Elsevier, Paris.

Ransome, R., 1990. The Natural History of Hibernating Bats. Helm, London.

Real, R., Vargas, J.M., Antúnez, A., 1993. Environmental influences on local amphibian diversity: the role of floods on river basins. Biodiversity and Conservation 2, 376e399.

Rodríguez, A., Delibes, M., 1992. Food habits of badgers (Meles meles) in an arid habitat. Journal of Zoology (London) 227, 347e350.

Sánchez-Piñero, F., 2007. Diversidad en ambientes mediterráneos: la fauna de coleópteros de zonas áridas del sureste peninsular. In: Barea, M., Moleón, M., Travesí, R., Ballesteros, E., Luzón, J.M., Tierno, J.M. (Eds.), Biodiversidad y conservación de fauna y flora en ambientes mediterráneos. Soc. Granatense de Historia Natural, Granada, pp. 335 e353.
Sánchez-Zapata, J.A., Carrete, M., Gavrilov, A., Sklyarenko, S., Ceballos, O., Donazar, J.A., Hiraldo, F., 2003. Land use changes and raptor conservation in steppe habitat of Eastern Kazakhstan. Biological Conservation 111, 71e77.

Schleich, H.H., Kästle, W., Kabisch, K., 1996. Amphibians and Reptiles of North Africa. Koeltz Scientific Books, Koenigstein.

Serrano, E., Calabuig, G., Cassinello, J., Granados, J.E., Pérez, J.M., 2002. Corología del árrui Ammotraguslervia en el sureste peninsular. Galemys 14, 17e29.

Shkedy, Y., Safriel, U.N., 1992. Nest predation and nestling growth rate of two lark species in the Negev Desert, Israel. Ibis 134, 268 e272.

Soler, M., Zúñiga, J.M., Camacho, I., 1982. Nidificación de Picus viridis en taludes de arcilla en ramblas de Guadix (Granada). Doñana, Acta Vertebrata 9, $195 e 209$.

Suárez, F., Fernández, A., de Lope, M.J., 1986. Note sur les effects de l'aridité sur la structure et la composition des communautes de Passeriformes des hautsplateaux a alpha (Stipa tennacissima) au Maroc. Bulletin de l'Institute Scientifique, Rabat 10, 185e192.

Suárez, F., Sainz, H., Santos, T., González Bernáldez, F., 1991. Las estepas ibéricas. MOPT, Madrid.

Suárez, F., Yanes, M., Herranz, J., Manrique, J., 1993. Nature reserves and the conservation of Iberian shrubsteppe passerines: the paradox of nest predation Biological Conservation 63, 77e81.

Suárez, F., Herranz, J., Yanes, M., 1996. Conservación y gestión de las estepas en la España peninsular. In: Fernández, J., Sanz-Zuasti, J. (Eds.), Conservación de las aves esteparias y su hábitat. Junta de Castilla y León, Valladolid, pp. 19e25.

Suárez, F., Hervás, I., Herranz, J., 2009. Las alondras de España peninsular. Dirección General para la Biodiversidad, Madrid.

Suárez, F., 1992. Las estepas ibéricas. MOPT, Madrid.

Suárez, F. (Ed.), 2010. La alondra ricotí (Chersophilus duponti). Dirección General para la Biodiversidad. Ministerio de Medio Ambiente y Medio Rural y Marino, Madrid.

Sullivan, B.K., 1982. Sexual selection in Woodhouse's toad (Bufo woodhousei) I. Chorus organization. Animal Behaviour 30, 680e686.

Tejedo, M., Reques, R., Gasent, J.M., González de la Vega, J.P., Morales Brarnestein, J., García Cardenote, L., González Miras, E., Donaire, D., Sánchez Herráiz, M.J., Marangoni, F., 2003. Distribución de los anfibios endémicos de Andalucía: Estudio genético y ecológico de las poblaciones. Convenio CSIC-Consejería Medio Ambiente-Junta de Andalucía. Unpublished Technical Report.

Tellería, J.L., Santos, T., Suárez, F., 1988. Bird communities of the Iberian shrubsteppes: seasonality and structure along a climatic gradient. Holarctic Ecology 11, 171 e177.

Tevis, L., 1966. Unsuccessful breeding by desert toads (Bufo punctatus) at limit of their ecological tolerance. Ecology 47, 766e775.

Tompkins, D.M., Draycott, R.A.H., Hudson, P.J., 2000. Field evidence for apparent competition mediated via the shared parasites of two gamebird species. Ecology Letters 3, 10e14.

Torralva, M., Oliva, F.J., Egea, A., Miñano, P.A., Verdiell, D., De Maya, J.A., Andreu, A., 2005. Atlas de distribución de los anfibios de la Región de Murcia. Univ. Murcia, Graf. F. Gómez, Cartagena.

Václav, R., Valera, F., Martínez, T., 2011 Social information in nest colonisation and occupancy in a long-lived, solitary breeding bird. Oecologia 165, 617e627.

Valera, F., Casas-Crivillé, A., Hoi, H., 2003. Interspecific parasite exchange in a mixed colony of birds. Journal of Parasitology 89, 245e250.

Valle, F. (Ed.), 2003. Mapa de las series de vegetación de Andalucía. Junta de Andalucía-Ed. Rueda, Madrid.

Valverde, J.A., 1964a. Estructura de una comunidad de Vertebrados terrestres. Monogr. Estación Biológica de Doñana 1, 1 e129.

Valverde, J.A., 1964b. Remarques sur la structure et l'evolution des communautés de vertébrés terretres. I: structure d'une communaut é. II: rapports entre pré dateurs et proies. Terre et Vie 111, 121e154.

Vera, J.A. (Ed.), 2004. Geología de España. SGE-IGME, Madrid.

Vericad, J.R., Escarré, A., Rodríguez, E., 1975. Datos sobre la dieta de Tyto alba y Bubo bubo en Alicante (SE de Iberia). Mediterranea 1, 47e59.

Vögeli, M., Serrano, D., Pacios, F., Tella, J.L., 2010. The relative importance of patch habitat quality and landscape attributes in a declining steppe-bird metapopulation. Biological Conservation 143, 1057 e1067.

Wells, K.D., 2007. The ecology and behavior of amphibians. University of Chicago Press, Chicago, IL.

Wilson, D.E., Mittermeier, R.A. (Eds.), 2009. Handbook of the Mammals of the World. Carnivores, vol. 1. Lynx, Barcelona.

Yanes, M., Delgado, J.M., 2006. Aves esteparias en Andalucía. Bases para su conservación. In: Manuales de Conservación de la Naturaleza, vol. 3. Consejería de Medio Ambiente, Sevilla.

Yanes, M., Suárez, F., 1995. Nest predation patterns in ground-nesting passerines on the Iberian Peninsula. Ecography 18, $423 e 428$.

Yanes, M., Suárez, F., 1996a. Incidental nest predation and lark conservation in an Iberian semiarid shrubsteppe. Conservation Biology 10, 861 e867.

Yanes, M., Suárez, F., 1996b. Mortalidad en nido y viabilidad poblacional en aláudidos. Ardeola 43, 55e66.

Yanes, M., Suárez, F., 1997. Nest predation and reproductive traits in small passerines: a comparative approach. Acta Oecologica 1 (8), $413 e 426$. 